\title{
Hubungan Derajat Keparahan DBD Dengan Kadar Albumin Pada Penderita Demam Berdarah Dengue Di RSUD Dr. H. Abdul Moeloek Provinsi Lampung
}

\author{
Nurminha ${ }^{1}$, Mimi Sugiarti ${ }^{1}$, Mahrifa Gita Aulia ${ }^{2}$ \\ ${ }^{1}$ Prodi Diploma IV Analis Kesehatan Poltekkes Tanjungkarang \\ ${ }^{2}$ Alumni Prodi Diploma IV Analis Kesehatan Poltekkes Tanjungkarang
}

\begin{abstract}
Abstrak
Demam Berdarah Dengue adalah penyakit infeksi yang disebabkan oleh virus dengue dari famili Flaviviridae yang terdiri dari 4 serotipe yaitu DEN-1, DEN-2, DEN-3, dan DEN-4. Infeksi dengue memperlihatkan spektrum klinis yang bervariasi dari derajat ringan sampai berat. Pasien yang terinfeksi virus dengue sering ditemukan adanya peningkatan akut permeabilitas vaskuler yang mengarah pada perembesan plasma dengan bukti hipoalbuminemia. Penelitian ini bertujuan untuk mengetahui hubungan antara derajat keparahan DBD dengan kadar albumin pada penderita demam berdarah dengue di RSUD dr. H. Abdul Moeloek Provinsi Lampung. Jenis penelitian ini adalah analitik dengan desain cross sectional. Analisa data menggunakan uji korelasi Spearman dan dilanjutkan dengan uji Anova one way. Hasil penelitian menunjukkan dari 30 pasien didapatkan penderita DBD derajat I sebanyak 43.3\%, DBD derajat II sebanyak 33.3\%, DBD derajat III sebanyak $16.7 \%$, dan DBD derajat IV sebanyak 6.7\%. Rerata kadar albumin penderita DBD derajat I, II, III, dan IV berturut-turut $3.7 \mathrm{~g} / \mathrm{dL}, 3.2 \mathrm{~g} / \mathrm{dL}, 3.1 \mathrm{~g} / \mathrm{dL}$, dan $2.4 \mathrm{~g} / \mathrm{dL}$. Uji korelasi Spearman didapatkan $p$ value $0.000(\mathrm{p}<0.05)$ dengan nilai koefisien korelasi $(\mathrm{r}=-0.737)$ dan pada uji Anova diperoleh $p$-value 0.000 $(\mathrm{p}<0.05)$ menunjukkan bahwa ada hubungan yang bermakna antara derajat keparahan DBD dengan kadar albumin penderita DBD.
\end{abstract}

Kata Kunci : Albumin, Derajat Keparahan, Demam Berdarah Dengue

\section{Relationship Degree Of Severity Dhf With Albumin To Patients Dengue Hemorrhagic Fever In RSUD Dr. H. Abdul Moeloek The Lampung Province}

\begin{abstract}
Dengue Hemorrhagic Fever is an infectious disease caused by the dengue virus from the family Flaviviridae which consists of 4 serotypes namely DEN-1, DEN-2, DEN-3, and DEN-4. Dengue infection shows a clinical spectrum that varies from mild to severe. In patients infected with dengue virus, there is often an acute increase in vascular permeability that leads to plasma permeability with evidence of hypoalbuminemia. This study aims to determine the relationship between the degree of severity of DHF and albumin levels in patients with dengue hemorrhagic fever in RSUD dr. H. Abdul Moeloek Lampung Province. This type of research is analytic with cross sectional design. Data analysis used Spearman correlation test and continued with one way Anova test. The results showed a sample of 30 patients with a percentage of DHF patients with grade I as much as $43.3 \%$, DHF degree II as much as $33.3 \%$, DHF grade III as much as $16.7 \%$, and DHF grade IV as much as $6.7 \%$. The mean albumin levels of DHF patients with grade I, II, III, and IV were $3.7 \mathrm{~g} / \mathrm{dL}, 3.2 \mathrm{~g} / \mathrm{dL}, 3.1 \mathrm{~g} / \mathrm{dL}$, and $2.4 \mathrm{~g} / \mathrm{dL}$, respectively. Spearman correlation test found $p$-value $0.000(p<0.05)$ with correlation coefficient value $(r=$ $0.737)$ and in Anova test obtained $p$-value $0.000(\mathrm{p}<0.05)$ showed that there was a significant relationship between the degree of dengue severity and albumin levels DHF sufferers.
\end{abstract}

Keywords: Albumin, Degree of Severity of Dengue Hemorrhagic Fever

Korespondensi: Nurminha,S.Pd.,M.Sc, Jurusan Analis Kesehatan, Politeknik Kesehatan Tanjungkarang, Jalan Soekarno-Hatta No. 1 Hajimena Bandar Lampung, mobile 0821850633737, e-mail Nurminha1@gmail.com 


\section{Pendahuluan}

Penyakit demam berdarah dengue disebabkan oleh virus dengue dari kelompok arbovirus b, yaitu arthropoda-borne virus atau virus yang disebarkan oleh artropoda. Virus ini termasuk genus Flavivirus dari famili Flaviviridae. Demam berdarah dengue adalah penyakit infeksi yang disebabkan oleh virus dengue yang termasuk dalam genus Flavivirus dan terdiri dari 4 serotipe yaitu DEN-1, DEN-2, DEN-3, dan DEN-4. Demam berdarah dengue ditegakkan berdasarkan kriteria WHO yaitu kriteria klinis meliputi demam tinggi mendadak tanpa sebab yang jelas dan berlangsung terus-menerus selama 2-7 hari, terdapat manifestasi perdarahan, pembesar- an hati, dan syok. Kriteria laboratories yaitu trombositopenia (jumlah trombosit $<100.000 / \mu 1)$ dan hemokon- sentrasi (hematokrit meningkat >20\%) (Widoyono, 2011).

Faktor-faktor yang mempengaruhi peningkatan dan penyebaran kasus demam berdarah dengue sangat kompleks, yaitu pertumbuhan penduduk, urbanisasi yang tidak terkontrol, dan peningkatan sarana transportasi. Sedangkan faktor morbiditas dan mortalitas penyakit dengue yaitu imunitas pejamu, kepadatan vektor nyamuk, transmisi virus dengue, keganasan virus dengue, dan keadaan geografis setempat (Widoyono, 2011).

Pada tahun 2015 jumlah penderita demam berdarah dengue di Indonesia yang dilaporkan sebanyak 129.650 kasus (angka kesakitan sebesar 50,75 per 100.000 penduduk) dengan jumlah kematian sebanyak 1.071 orang (angka kematian 0,83\%). Dibandingkan tahun 2014 dengan kasus sebanyak 100.437 terjadi peningkatan kasus pada tahun 2015. Target Renstra Kementerian Kesehatan untuk angka kesakitan demam berdarah dengue tahun 2015 sebesar < 49 per 100.000 penduduk, dengan demikian Indonesia belum mencapai target Renstra 2015. Tahun 2015 terdapat sebanyak 34 provinsi yang terjangkit demam berdarah dengue. Jumlah Kabupaten/Kota terjangkit demam berdarah dengue pada tahun 2015 sama-sama mengalami peningkatan. Tahun 2014 sebesar $433 \quad(84,74 \%)$ menjadi 446 Kabupaten/Kota $(86.77 \%)$ pada tahun 2015 (Kemenkes, 2016).

Penyakit Demam Berdarah Dengue merupakan salah satu masalah kesehatan masyarakat di Indonesia khususnya Provinsi Lampung, di mana kasusnya cenderung meningkat dan semakin luas penyebarannya serta berpotensi menimbulkan kejadian luar biasa. Angka kesakitan (IR) selama tahun 20042012 cenderung berfluktuasi. Angka kesakitan demam berdarah dengue di Provinsi Lampung tahun 2012 sebesar 68,44 per 100.000 penduduk (di atas IR Nasional yaitu 55 per 100.000 penduduk). Distribusi dari angka kesakitan demam berdarah dengue di Kabupaten/Kota terlihat bahwa angka kesakitan tertinggi ada di Kota Metro yaitu sebanyak 256,78 per 100.000 penduduk dan Kota Bandar Lampung sebanyak 173,24 per 100.000 penduduk (Dinkes Lampung, 2013).

Angka kesakitan demam berdarah dengue di Provinsi Lampung tahun 2014 sebesar 16.8 per 100.000 penduduk (di bawah IR Nasional yaitu 51 per 100.000 penduduk). Angka kematian demam berdarah dengue di Provinsi Lampung terjadi peningkatan dari tahun 2013 sebanyak $0,98 \%$ dan pada tahun 2014 sebanyak 1,63\%. Angka kematian tertinggi ada di Kabupaten Mesuji sebesar 25\% dan Kota Bandar Lampung sebesar 5,9\%. (Dinkes Lampung, 2015).

Gambaran klinis demam berdarah dengue yaitu demam akut, perdarahan serta kecenderungan terjadi renjatan yang dapat berakibat fatal. Manifestasi klinis virus dengue diklasifikasikan menjadi empat, yaitu DBD derajat I, DBD derajat II, DBD derajat III, dan DBD derajat IV. DBD derajat I merupakan derajat beratnya penyakit yang ringan ditandai dengan demam akut dan manifestasi perdarahan paling ringan yaitu uji bendung positif. DBD derajat II ditemukan perdarahan kulit dan manifestasi perdarahan lain. DBD derajat III dan IV ditemukan adanya tandatanda dini terjadinya renjatan dengan tekanan darah dan nadi yang tidak terukur (Hendarwanto, 2004).

Trombositopenia dan hemokonsen- trasi adalah temuan tetap pada Demam Berdarah Dengue. Penurunan pada jumlah trombosit sampai dibawah $100.000 \mathrm{~mm}^{3}$ biasanya ditemukan antara hari ketiga dan kedelapan bersamaan dengan peningkat- an kadar hematokrit. Peningkatan kadar hematokrit yang menunjukkan adanya rembesan plasma selalu terjadi bahkan pada kasus non syok, tetapi lebih menonjol pada kasus syok. Hemokonsentrasi dengan peningkatan hematokrit lebih dari $20 \%$ dari nilai normal dianggap menjadi bukti definitif adanya peningkatan permeabilitas vaskuler dan rembesan plasma.

Pasien yang terinfeksi virus dengue sering juga ditemukan adanya peningkatan 
akut permeabilitas vaskuler yang mengarah kehilangan plasma dari kompartemen vaskuler. Studi menunjuk- kan penurunan volume plasma lebih dari $20 \%$ terjadi pada beberapa kasus. Bukti yang menunjukkan adanya rembesan plasma mencakup temuantemuan hemo- konsentrasi dan hipoproteinemia yang disebabkan karena kehilangan albumin (hipoalbuminemia) (WHO, 2014).

Hipoproteinemia atau penurunan konsentrasi protein total biasanya menun-jukan konsentrasi albumin yang rendah (hipoalbuminemia) (Gaw, 2011). Albumin merupakan komponen protein yang membentuk lebih dari $50 \%$ protein plasma. Protein ini dapat meningkatkan tekanan osmotik (tekanan onkotik) yang berperan penting untuk mempertahankan cairan vaskuler (Kee, 2014).

Pada pasien infeksi virus dengue, kadar albumin akan menurun seiring beratnya penyakit. Pada penyakit infeksi virus dengue akan ditemukan keadaan hipoalbuminemia. Kebocoran plasma yang diindikasikan hipoalbuminemia pada kasus dengue, merupakan indikator berat penyakit. Rendahnya kadar albumin yang diperoleh, menunjukkan adanya kerusakan endotel pembuluh darah yang menyebabkan terjadinya kebocoran plasma. Albumin yang terdapat di dalam plasma ikut merembes keluar dari pembuluh darah. Oleh karena itu, kadar albumin dapat dijadikan indikator kebocoran plasma dan bermanfaat untuk penanda prognostik (Villar, 2008). Berdasarkan hasil penelitian yang dilakukan Debby Nur Rachmawati diperoleh hasil hubungan derajat infeksi virus dengue dengan kadar albumin penderita demam berdarah memiliki korelasi negatif berderajat kuat dengan koefisien korelasi $(\mathrm{r}=0,699)$ (Rachmawati, 2012).

Rumah Sakit Umum Daerah dr. H. Abdul Moeloek merupakan Rumah Sakit tipe B yang berada di Bandar Lampung dan merupakan Rumah Sakit rujukan tertinggi di 15 kabupaten/kota di Provinsi Lampung. Berdasarkan data rekam medik di RSUD dr. H. Abdul Moeloek jumlah pasien DBD pada tahun 2016 mencapai 162 pasien.

\section{Metode}

Jenis penelitian ini adalah analitik dengan desain penelitian cross sectional. Variabel bebas, yaitu derajat keparahan DBD dan variabel terikat yaitu kadar albumin pada pasien
DBD yang dirawat di RSUD dr. H. Abdul Moeloek Provinsi Lampung. Penelitian ini dilaksanakan di RSUD dr. H. Abdul Moeloek Provinsi Lampung pada bulan MaretJuni 2017. Populasi penelitian ini adalah penderita DBD yang dirawat di UGD RSUD dr. H. Abdul Moeloek Provinsi Lampung sebanyak 41 sampel. Sampel yang digunakan sebanyak 30 sampel diambil dari seluruh populasi menggunakan teknik pengambilan sampel purposive sampling dengan kriteria yaitu, semua penderita DBD dengan IgG positif, IgM positif atau positif keduanya dengan trombositopenia, semua umur, laki-laki dan perempuan, bersedia menjadi responden dalam penelitian, tidak mempunyai penyakit hepatitis kronis, infeksi malaria, dan demam tifoid. Kriteria ekslusi yaitu penderita DBD yang sudah mendapat terapi pengobatan. Pemeriksaan serologi Dengue menggunakan metode Imunokromatografi assay. Tes ini juga dapat mendeteksi 4 serotipe dengue dengan menggunakan protein rekombinan dengue. Kedua monoklonal antihuman IgG dan IgM pada membran dan koloid emas antigen amplop virus dengue akan bereaksi secara khusus dengan IgG dan IgM.

Analisa data yang adalah Uji Korelasi Spearman dan Uji Anova dengan taraf kepercayaan 95\% (Dahlan, 2004.)

\section{Hasil}

Dari 30 penderita DBD, didapatkan penderita laki-laki sebanyak 14 responden $(46,7 \%)$ dan perempuan sebanyak 16 orang $(53,3 \%)$.

Tabel 1. Karakteristik responden berdasarkan

\begin{tabular}{ccc}
\hline $\begin{array}{c}\text { Usia } \\
\text { (Tahun) }\end{array}$ & $\begin{array}{c}\text { Jumlah } \\
\text { Responden }\end{array}$ & $\begin{array}{r}\text { usia } \\
\text { Persentase } \\
(\%)\end{array}$ \\
\hline $0-5$ & 1 & 3,3 \\
$6-11$ & 8 & 26,7 \\
$12-25$ & 8 & 26,7 \\
$26-45$ & 6 & 20,0 \\
$46-65$ & 7 & 23.3 \\
$>65$ & 0 & 0 \\
\hline Jumlah & $\mathbf{3 0}$ & $\mathbf{1 0 0}$ \\
\hline
\end{tabular}

Data pada tabel 1 menunjukkan usia terbanyak pada penderita DBD di RSUD dr. H. Abdul Moeloek Provinsi Lampung yaitu 6-11 tahun sebanyak 8 orang $(26.7 \%)$ dan $12-25$ tahun sebanyak 8 orang (26.7\%), dan tidak ada penderita yang berusia diatas 65 tahun. 
Tabel 2. Persentase penderita DBD berdasarkan derajat keparahan

\begin{tabular}{ccc}
\hline $\begin{array}{c}\text { Derajat } \\
\text { Keparaha } \\
\text { n DBD }\end{array}$ & $\begin{array}{c}\text { Jumlah } \\
\text { Responde } \\
\text { n }\end{array}$ & $\begin{array}{c}\text { Persent } \\
\text { ase } \\
\mathbf{( \% )}\end{array}$ \\
\hline I & 13 & 43,3 \\
II & 10 & 33,3 \\
III & 5 & 16,7 \\
IV & 2 & 6,7 \\
\hline Jumlah & $\mathbf{3 0}$ & $\mathbf{1 0 0}$ \\
\hline
\end{tabular}

Berdasarkan tabel 2 menunjukkan bahwa dari 30 penderita DBD didapatkan penderita DBD terbanyak yaitu pada derajat keparahan I sebanyak 13 orang (43.33\%).

Hasil penelitian menunjukkan bahwa rata-rata kadar albumin pada penderita DBD adalah $3.4 \mathrm{~g} / \mathrm{dL}$, serta kadar albumin terendah adalah $2.1 \mathrm{~g} / \mathrm{dL}$ dan kadar albumin tertinggi adalah $4.2 \mathrm{~g} / \mathrm{dL}$.

Tabel 3. Hubungan derajat keparahan DBD dengan kadar albumin pada penderita DBD di RSUD dr. H. Abdul Moeloek Provinsi Lampung

\begin{tabular}{lccccccccc}
\hline $\begin{array}{c}\text { No. } \\
\text { Keparahan } \\
\text { DBD }\end{array}$ & N & $\begin{array}{c}\text { Derajat } \\
\text { \% }\end{array}$ & $\begin{array}{c}\text { Penderita } \\
\text { Albumin } \\
\text { Normal } \\
\mathbf{N}\end{array}$ & \multicolumn{2}{c}{$\begin{array}{c}\text { DBD } \\
\text { Albumin } \\
\text { Rendah } \\
\mathbf{\%}\end{array}$} & p-value & $\begin{array}{c}\text { Kekuata } \\
\text { n } \\
\text { korelasi }\end{array}$ \\
\hline 1. & I & 13 & 43.3 & 6 & 20 & 7 & 23.3 & 0.00 & -0.737 \\
& & & & & & & & & \\
2. & II & 10 & 33.3 & 0 & 0 & 10 & 33.3 & & \\
3. & III & 5 & 16.7 & 0 & 0 & 5 & 16.7 & & \\
4. & IV & 2 & 6.7 & 0 & 0 & 2 & 6.7 & & \\
\hline & Jumlah & $\mathbf{3}$ & $\mathbf{1 0 0}$ & $\mathbf{2 0}$ & $\mathbf{2 4}$ & $\mathbf{1 0 0}$ & & \\
\hline
\end{tabular}

Tabel 3 menunjukkan bahwa penderita DBD derajat 1 sebanyak 13 orang yang memiliki kadar albumin rendah sebanyak 7 orang $(23.3 \%)$ dan yang memiliki kadar albumin normal sebanyak 6 orang (20\%). Penderita DBD derajat II, III, dan IV sebanyak 10 orang (33.3\%), 5 orang (16.7\%), dan 2 orang $(6.7 \%)$ dan seluruhnya memiliki kadar albumin rendah.
Hasil uji korelasi spearman diperoleh nilai $p$-value $0.000(\alpha<0.05)$ yang artinya Ho ditolak, yang berarti ada hubungan antara derajat keparahan DBD dengan kadar albumin pada penderita DBD di RSUD dr. H. Abdul Moeloek Provinsi Lampung. Koefisien korelasi sebesar -0.737 menunjukkan hubungan yang kuat dengan arah korelasi negatif.

Tabel 4. Uji post hoc perbedaan derajat keparahan terhadap kadar albumin penderita DBD

\begin{tabular}{lccll}
\hline \multicolumn{1}{c}{ Derajat Keparahan DBD } & $\begin{array}{c}\text { Perbedaan } \\
\text { Rerata }\end{array}$ & P-value & Keterangan \\
\hline DBD derajat I vs DBD derajat II & $0.44538^{*}$ & 0.002 & Berbeda nyata \\
DBD derajat I vs DBD derajat III & $0.57538^{*}$ & 0.002 & Berbeda nyata \\
DBD derajat I vs DBD derajat IV & $1.26538^{*}$ & 0.000 & Berbeda nyata \\
DBD derajat II vs DBD derajat III & 0.13000 & 0.459 & Tidak berbeda nyata \\
DBD derajat II vs DBD derajat IV & $0.82000^{*}$ & 0.002 & Berbeda nyata \\
DBD derajat III vs DBD derajat IV & $0.69000^{*}$ & 0.015 & Berbeda nyata \\
\hline
\end{tabular}

Hasil uji Post Hoc tabel 4 menunjukkan adanya perbedaan yang nyata pada DBD derajat I dengan derajat II, III, IV, dan pada DBD derajat II dengan derajat IV, serta pada
DBD derajat III dengan derajat IV. Namun tidak terdapat perbedaan yang nyata antara DBD derajat II dengan DBD derajat III. 


\section{Pembahasan}

Penelitian ini dilakukan pada pasien penderita DBD sebanyak 30 orang responden terdiri dari 14 orang $(46.7 \%)$ laki - laki dan 16 orang $(53.3 \%)$ perempuan.

Penderita DBD pada penelitian ini didapatkan kelompok usia anak - anak (6-11 tahun) yaitu sebanyak $26.7 \%$. Usia adalah salah satu faktor yang mempengaruhi kepekaan terhadap infeksi virus dengue, semua golongan umur dapat diserang virus dengue tetapi anak-anak berumur muda terbukti paling peka terhadap serangan virus dengue (Gatot, 2002). Hasil penelitian pada kelompok usia anak-anak (0-11 tahun) DBD derajat keparahan I sebanyak 4 orang, DBD derajat keparahan II sebanyak 3 orang, dan DBD derajat keparahan III dan IV sebanyak masing-masing 1 orang. Hal ini dikarenakan makin muda usia pasien DBD, maka makin tinggi mortalitasnya. Kerentanan untuk terjadi syok relatif konstan antara umur 4-12 tahun dan menurun pada usia remaja. Usia anak-anak yang lebih muda endotel pembuluh darah kapiler lebih rentan terjadi pelepasan sitokin sehingga memicu terjadinya peningkatan permeabilitas kapiler (Soedarmo, 2002)

Sistem respon imun penderita DBD, setelah virus masuk dalam tubuh manusia, virus berkembang biak dalam sel retikuloendotelial yang selanjutnya diikuti dengan viremia yang berlangsung 5-7 hari. Akibat infeksi virus ini muncul respon imun baik humoral maupun selular, antara lain anti netralisasi, anti hemaglutinin, anti komplemen. Antibodi yang muncul pada umumnya adalah IgG dan IgM. Infeksi dengue primer antibodi mulai terbentuk dan pada infeksi sekunder antibodi yang telah ada akan meningkat.

Antibodi terhadap virus dengue dapat ditemukan di dalam darah sekitar demam hari ke-5, meningkat pada minggu pertama sampai dengan ketiga, dan menghilang setelah 60-90 hari. Kinetik kadar antibodi IgG berbeda dengan kinetik kadar antibodi IgM. Oleh karena itu kinetik antibodi IgG harus dibedakan antara infeksi primer dan sekunder. Pada infeksi primer antibodi IgG meningkat sekitar demam hari ke-14 sedangkan pada infeksi sekunder antibodi IgG meningkat pada hari kedua. Oleh karena itu diagnosa dini infeksi primer hanya dapat ditegakkan dengan mendeteksi antibodi IgM setelah hari sakit kelima, diagnosis infeksi sekunder dapat ditegakkan lebih dini dengan adanya peningkatan antibodi $\operatorname{IgG}$ dan IgM yang cepat (Soegijanto, 2006).
Persentase derajat keparahan penderita DBD yang paling banyak adalah derajat keparahan I yaitu sebanyak 13 penderita $(43.3 \%)$ dari 30 penderita DBD.

Penderita DBD dengan derajat keparahan I tidak adanya tanda-tanda syok, baik hipotensi maupun tekanan darah yang tidak terukur, namun, diperoleh uji bendung yang positif, hal ini menunjukkan tanda-tanda perdarahan dalam skala yang ringan akibat rusaknya pembuluh darah kapiler (WHO, 2014).

Kadar albumin penderita DBD pada penelitian ini memiliki rerata $3.4 \mathrm{~g} / \mathrm{dL}$. Ratarata kadar albumin pada penderita DBD derajat I, II, III, IV adalah $3.7 \mathrm{~g} / \mathrm{dL}, 3.2 \mathrm{~g} / \mathrm{dL}, 3.1$ $\mathrm{g} / \mathrm{dL}$, dan $2.4 \mathrm{~g} / \mathrm{dL}$, ini berarti kadar albumin penderita DBD lebih rendah dari nilai normal. Kadar albumin terendah terdapat pada pasien penderita DBD derajat IV yaitu $2.1 \mathrm{~g} / \mathrm{dL}$. Penderita DBD yang memiliki kadar albumin rendah sebanyak 24 orang $(80 \%)$ dari 30 penderita DBD. Rendahnya kadar albumin yang diperoleh, menunjukkan adanya kerusakan endotel pembuluh darah yang menyebabkan terjadinya kebocoran plasma pada pasien DBD derajat IV. Penderita DBD yang memiliki kadar normal sebanyak 6 orang $(20 \%)$, hal ini disebabkan karena kebocoran plasma merupakan rentang waktu dari hari ketiga sampai ketujuh, sehingga saat pengambilan sampel belum tentu merupakan puncak dari kebocoran plasma (Hendarwanto, 2004).

Hasil uji statistik antara kadar albumin dan derajat keparahan DBD menggunakan uji statistik spearman didapatkan hasil korelasi negatif dengan derajat kuat $(\mathrm{p}=0.000)$ dengan koefisien korelasi (r) sebesar -0.737. Maka hipotesa Ho ditolak, dengan ditolaknya Ho maka H1 diterima, ini berarti bahwa ada hubungan derajat keparahan DBD dengan kadar albumin pada penderita DBD. Patogenesis utama yang menyebabkan kematian pada hampir seluruh pasien DBD baik DBD derajat I,II,III, maupun IV adalah renjatan karena perembesan plasma. Kebocoran vaskuler merupakan patofisiologi dari DBD, ini dikarenakan permebilitas kapiler lebih tinggi terhadap cairan maupun molekul besar dan kecil (Hendarwanto, 2004).

Syok dapat menjadi berat dengan berbagai penyulitnya seperti asidosis metabolik, perdarahan hebat saluran cerna, sehingga memperburuk prognosis. Perembesan plasma diduga terjadi karena proses imunologi dan kerusakan endotel. Hal ini disebabkan karena pelepasan zat anafilaktosin, histamin dan 
serotonin serta aktivasi sistem kalikrein yang berakibat ekstravasasi cairan intravaskuler dan protein, terutama albumin ke dalam rongga diantara jaringan ikat dan serosa. Hal ini berakibat mengurangnya volum plasma, terjadinya hemokonsentrasi, hipoproteinemia, efusi dan renjatan. Pada pasien dengan renjatan berat, volume plasma dapat menurun sampai lebih dari 30\%.

Adanya kebocoran plasma ke daerah ekstravaskular dibuktikan dengan ditemukannya cairan dalam rongga serosa, yaitu rongga peritoneum, pleura dan perikard. Renjatan hipovolemik yang terjadi sebagai akibat kehilangan plasma, bila tidak segera diatasi dapat berakibat anoksia jaringan, asidosis metabolik dan kematian. Sebab lain kematian pada DBD adalah perdarahan hebat, yang biasanya timbul setelah renjatan berlangsung lama dan tidak teratasi (Hendarwanto, 2004).

Kadar albumin pada DBD derajat I yang dibandingkan dengan DBD derajat II hasilnya terdapat perbedaan yang bermakna antara keduanya dengan p-value 0.002 , hal berbeda terjadi jika DBD derajat II dibandingkan dengan DBD derajat III , hasilnya tidak terdapat perbedaan yang bermakna $p$-value 0.459 . Hal ini dikarenakan pada DBD derajat I diperoleh uji bendung yang positif yang menunjukkan adanya perdarahan dalam skala ringan akibat rusaknya pembuluh darah kapiler. Namun, pada DBD derajat II selain uji bendung yang positif disertai juga timbulnya perdarahan yang spontan seperti perdarahan mukosa, saluran cerna, hematemesis dan melena (WHO, 2014). Kadar albumin serum berhubungan dengan terjadinya perdarahan spontan pada infeksi dengue, dimana kadar albumin serum yang rendah berhubungan dengan kemungkinan yang lebih tinggi untuk terjadinya perdarahan spontan (Saraswati, 2007). Dalam penelitian ini diperoleh bahwa rerata kadar albumin pada DBD derajat II lebih rendah daripada DBD derajat I. Pada DBD derajat II dan III tidak diperoleh perbedaan kadar albumin yang bermakna. Pada penelitian ini diperoleh rerata kadar albumin DBD derajat III lebih rendah daripada DBD derajat II. Pada penelitian ini walaupun rerata pada DBD derajat III lebih rendah, namun secara statistik tidak memiliki perbedaan yang bermakna $(p>0.05)$. Hal ini dapat disebabkan karena pemeriksaan kadar albumin yang hanya dilakukan satu kali, padahal belum tentu pada saat pengambilan sampel tersebut merupakan puncak dari kebocoran plasma.
Upaya untuk mencegah penyakit DBD lebih parah, maka setiap ada kasus DBD harus dimonitor kerusakan endotel pembuluh darah sebagai indikator awal kebocoran plasma yang merujuk pada terjadinya syok dengan melakukan pemeriksaan albumin sebagai parameter berat ringannya penyakit.

Hasil penelitian ini juga sejalan dengan penelitian sebelumnya oleh Debby Nur Rachmawati (2012) dengan judul penelitian "Hubungan kadar kolesterol total dan kadar albumin dengan derajat infeksi dengue pada anak" yang melaporkan adanya hubungan derajat infeksi dengue dengan kadar albumin pada penderita DBD.

Simpulan penelitian ini adalah terdapat hubungan derajat keparahan DBD dengan kadar albumin pada penderita DBD demam berdarah dengue dengan p-value $0.000(\mathrm{p}<$ $0.05)$. Persentase derajat keparahan penderita DBD derajat I sebanyak 43.3\%, DBD derajat II sebanyak $33.3 \%$, DBD derajat III sebanyak 16.7\%, dan DBD derajat IV sebanyak $6.7 \%$. Rata-rata kadar albumin pada penderita yang dirawat yang dirawat di RSUD dr. H. Abdul Moeloek Provinsi Lampung adalah $3.4 \mathrm{~g} / \mathrm{dL}$. Rata-rata kadar albumin pada penderita DBD derajat I, II, III, dan IV adalah $3.7 \mathrm{~g} / \mathrm{dL}, 3.2 \mathrm{~g} / \mathrm{DL}, 3.1 \mathrm{~g} / \mathrm{dL}$, dan $2.4 \mathrm{~g} / \mathrm{dL}$, ini berarti kadar albumin penderita demam berdarah dengue lebih rendah dari nilai normal. Nilai terendah kadar albumin adalah $2.1 \mathrm{~g} / \mathrm{dL}$ dan nilai tertinggi kadar albumin penderita DBD adalah $4.2 \mathrm{~g} / \mathrm{dL}$.

Saran pada penelitian ini adalah perlu dilakukannya pemeriksaan kadar albumin pada penderita demam berdarah dengue sebagai indikator awal terjadinya kebocoran plasma untuk penunjang diagnosa dokter. Pada pihak terkait yaitu Dinas Kesehatan Provinsi Lampung memberikan informasi kepada masyarakat tentang bahaya penyakit DBD dan komplikasi yang dapat dialami oleh pasien DBD.

\section{Daftar Pustaka}

1. Dahlan, M. Sopiyudin 2004, Statistika Untuk Kedokteran dan Kesehatan, Arkans, Jakarta

2. Kemenkes 2016, Profil Kesehatan Indonesia tahun 2015, Kementerian Kesehatan Republik Indonesia 
3. Dinas Kesehatan Provinsi Lampung 2013, Profil Kesehatan Provinsi Lampung Tahun 2012, Lampung.

4. Dinas Kesehatan Provinsi Lampung 2015, Profil Kesehatan Provinsi Lampung Tahun 2014, Lampung.

5. Gatot, Djajadiman 2002, "Perubahan Hematologi pada Infeksi Dengue" di dalam Hadinegoro, S Rezeki H, Satari, H. Irawan, (Ed.), Demam Berdarah Dengue, Balai Penerbit FKUI, Jakarta.

6. Gaw, dkk 2011, Biokimia Klinis Edisi 4, EGC, Jakarta.

7. Hadinegoro, Sri Rezeki, dkk 2002, "Tatalaksana Demam Dengue/Demam Berdarah Dengue Pada Anak", di dalam Hadinegoro, S, Rezeki H, Satari, H, Irawan., (Ed.), Demam Berdarah Dengue, Balai Penerbit FKUI, Jakarta.

8. Hendarwanto 2004, "Dengue", di dalam Tjokronegoro, Arjatmo. Hendra Utama, Ilmu Penyakit Dalam Jilid 1 Edisi 2, Balai Penerbit FKUI, Jakarta.

9. Kee, Joyce Lefever 2014, Pedoman Pemeriksaan Laboratorium \& Diagnostik Edisi 6, EGC, Jakarta.

10. Rachmawati, Debby Nur 2012, Hubungan kadar kolesterol total dan kadar albumin derajat infeksi dengue padaanak, FK UNDIP, Semarang.

11. Saraswati, Made Ratna, merati, Parwati KT, Bakta, I made 2007, Faktor-faktor yang berhubungan dengan perdarhan spontan pada infeksi virus dengue,. Medicina

12. Soegijanto, S 2006, Patogenesis dan Perubahan Fisiologi Infeksi Virus Dengue. Suhendro, dkk 2009 "Demam Berdarah Dengue", di dalam Aru W. Sudoyo (Ed.), Buku Ajar Ilmu Penyakit Dalam Edisi Kelima

13. Soedarmo, Sumarmo 2002, "Masalah Demam Berdarah Dengue di Indonesia" di dalam Hadinegoro, S Rezeki H, Satari, H. Irawan, (Ed.), Demam Berdarah Dengue, Balai Penerbit FKUI, Jakarta.
14. Villar, LA, Diaz FA, Martinez RA 2008, Biochemical Alterations as Markers of Dengue Hemorrhagic Fever, Am. J. Trop. Med. Hyg.

15. WHO 2014,Demam Berdarah Dengue Diagnosis, Pengobatan, Pencegahan, Dan Pengendalian. EGC, Jakarta.

16. Widoyono 2011, Penyakit Tropis, Epidemiologi, Penularan, Pencega han dan Pemberantasan. Erlangga, Jakarta. 